\title{
CUSTOMER TRUST TOWARDS BANKS AND THEIR PERCEPTIONS OF CORRUPTION BEFORE AND AFTER A BANKING CRISIS: THE CASE OF ICELAND
}

\author{
Thorhallur Gudlaugsson, School of Business, University of Iceland, Reykjavik, Iceland \\ Fridrik Eysteinsson, School of Business, University of Iceland, Reykjavik, Iceland
}

dx.doi.org/10.18374/JABE-13-2.2

\begin{abstract}
In October 2008 three of the biggest banks in Iceland went bankrupt along with the biggest savings and loans. The consequences have been dire for the Icelandic economy in general and the banking sector in particular. This applies especially to the banks' image. Their customer trust was ruined and they were perceived as corrupt. This paper deals with the research question: "What is the relationship between customer trust towards banks and their perceptions of corruption before and after a banking crisis?" Knowing this is important because if there is a relationship between customer trust and their perceptions of corruption, as earlier research might indicate, the former could possibly be restored by changing the latter. The population of interest was the customers of the Icelandic banks. A convenience sample was used. This paper presents the findings on two of the banks' image attributes; trust and corruption, both before and after the banking crisis in Iceland in October 2008. The surveys were web-based and done in February and March 2007 to 2012. The results indicate that the scores for customer trust towards banks and their perceptions of corruption mirror each other both before and after a banking crisis.
\end{abstract}

Keywords: Customer trust; Corruption; Banking sector, Banks, Banking crisis 